\author{
OLENA TROITSKA, \\ Bogdan Khmelnitsky Melitopol State Pedagogical University (Melitopol, Ukraine) \\ e-mail: troizka2015@ukr.net, ORCID0000-0003-4330-084X
}

OLGA POPRAVKO,

Bogdan Khmelnitsky Melitopol State Pedagogical University (Melitopol, Ukraine)

e-mail: popravko_olga@ukr.net, ORCID0000-0002-4765-2300

NINA SHCHERBAKOVA,

Dmytro Motornyi Tavria State Agrotechnological University (Melitopol, Ukraine)

e-mail:rnk-07@ukr.net,ORCID0000-0003-2632-2641

\title{
ASPECTS OF THE "CARNIVALIZATION" OF CONTEMPORARY CULTURAL PRACTICES
}

The relevance of the article is due to the need to reflect on a new cultural phenomenon that presents the cultural practices of modern chronotopos. The philosophical and cultural concepts of the state of culture are analyzed and the tendencies reflecting instability (transitivity), uncertainty, ambivalence of cultural practices and carnivalization of all spheres of life are revealed. The philosophical reflection of the essence, character, signs of carnivalization made it possible to explicate the phenomenon of "carnival" through its ideological and behavioral components. In the context of the dialogue of medieval and contemporary culture, the essence of carnivalization as a phenomenon of culture is revealed. This context is considered as a special means of restoring the integrity of worldview, world outlook, world attitude. The problem of cultural practices orientation to their value-semantic (axiological) uplift is also actualized. The nature and essence of such categories as "carnival laughter", "carnival freedom", "carnival behavior", "ambivalence" are investigated, characteristic features of carnivalisation are identified and it can be considered as a way of modeling and constructing contemporary cultural reality. The fact that the modern cultural space creates conditions not only for the functioning of carnivalization within the primary function - renewal, creation of a new life-world, but also a new world-view and meaning-making. The constructive role of cultural dialogue in the process of praxeological growth of the subjects of carnivalization has been determined. It is shown that the concept of carnivalization of Mikhail Bakhtin remains relevant at the present stage of cultural development. The discovery of carnivalization as a certain signal of the crisis of culture and the way out of it gives reason to consider carnivalization as a factor of self-organization of culture, as a complex organized system.

Key words: axiology; dialogue of cultures; carnivalization; carnival behavior; carnival outlook; crisis of culture; cultural practices; cultural meanings.

Introduction

Most contemporary philosophers of cultural scholars recognize the fact that the history of culture is not simply a series of stages. It is a complex nonlinear motion that proceeds at different speeds at different levels and in different spheres of culture (V. Bychkov, K. Galton, B. Groys, M. Zagibalova, N. Mankovskaya, V. Samokhin, O. Semenov, etc.). Cardinal changes take place in all spheres of human life and even in its ontological foundations, resulting in the cultural existence of man becoming dysentric. Characterizing the current state of culture, Michel Foucault notes that "we live without special markings and primordial coordinates in a myriad of lost events." This gives reason to talk about "changing cultural paradigms". Important in this context is the identification of such a tendency as the change of "sustainable" cultural epochs "transitional", and accordingly actualize the need to understand the "border" or "transitional" stages.

One of the manifestations of the current state of cultural development is the "blurring" of the boundaries between the holidays and weekdays, the interpenetration of festi- vities and everyday life, which leads to the formation of a new chronotope. This process is reflected in the phenomenon of carnivalization, which is considered as a "long carnival" (S. Vorkachov, A. Kozintsev, N. Khrenov). Carnivalization reflects the specifics of the modern culture as a whole, manifesting itself in completely different aspects this is the carnivalization of working hours, and the carnivalization of sports, and the carnivalization of politics, and the carnivalization of religion, etc. The various manifestations of carnivalisation that we observe in contemporary culture fully reflect the instability (transience) of the current state of culture. Because carnival, as a form of holiday, reproduces the moment of phase transition in the natural cycle. Mikhail Bakhtin said that "the most stressful and productive life of culture takes place on the border of spheres, industries, phenomena, epochs" (Bakhtin, 1965: 348-349). But to accept these changes, you need their carnival awareness and appropriate carnival (festive) design.

Researchers consider the phenomenon of carnivalization as a necessary condition "for self-organization of any complex system, including culture" Researchers con- 
sider the phenomenon of carnivalization as a necessary condition "for self-organization of any complex system, including culture" (M. Zagibalova (2011), Y. Lotman (1992), Y. Semenova (2013), V. Nazintsev (1997), U. Eko (2007)). We share the view of scientists who consider the carnivalization of modern culture as a signal of crisis and at the same time a way of exiting it, as well as a kind of unstructured "carnival feeling" that determines the process of formation of carnival culture (M. Bakhtin (1965), M. Zagibalova (2013), M. Khrenov (1997), O. Maltseva (2018), M. Sharnina (2017), L. Bandlamudi (2015), J. Braun (2012)).

The purpose of the article is the axiological definition of carnivalization as a phenomenon of modern cultural practices and as a method and construct of restoring the integrity of worldview, world outlook and value-semantic attitude of a person in a crisis of culture.

\section{Methods}

General scientific and specific cultural methods were used during the research. The philosophical and methodological background of the study is the anthropological, axiological, dialogical, phenomenological approaches to the interpretation of modern cultural concepts and understanding the essence of carnivalization as a phenomenon of culture. The methods of structural, functional analysis, theoretical reconstruction, content analysis and certain cognitive procedures (explication, reflection, etc.) were used at the level of scientific methodology. A cultural approach was used to make sense of carnivalization as a cultural practice. A semiotic analysis method was used to illuminate the praxeological aspects of carnivalization at the current transitional stage of cultural development.

Results and Discussion

In the early stages of cultural development, there was a dual aspect of perception of the world and human life. The primitive peoples, along with the serious cults, were born laughable, alongside their heroes - their parody counterparts, doublers. The whole world of ancient rituals was built to some extent as a parody of ordinary life. He perceived the logic of the inverse - the infinite movements of the top and bottom: the celestial and terrestrial, polar parts of the human body. Everything seemed to be a relative, worthy, indulgent smile. This is the dual nature of the worldview characteristic of carnival culture, the basis of which is the existence of two worlds - the everyday and the festive. It is most clearly manifested in festive forms of medieval culture, in particular in carnivals. The carnival was a temporary suspension of the entire official system, with all its prohibitions and hierarchical barriers: life briefly descended from its usual track and entered the realm of "utopian freedom". It was a kind of triumph for the temporary release from the ruling power and the existing system, the temporary abolition of all hierarchical relations, privileges, norms and prohibitions. The festive crowd perceived life through the prism of "fun relativity". In the grotesque imagery of the carnival, the moment of temporary change was strongly emphasized, symbolizing the people's hope for a better future, a fairer socio-economic system, a new truth. Everything perpetuated, completed was hostile to him. The carnival was aimed at an endless future. In the conditions of formation of a new socio-cultural space, the carnival continued its existence, undergoing certain changes, but at the same time maintaining its main function - updating, becoming a new one.

The first philosophical and cultural analysis of the carnival as a form of festive culture was carried out by Mikhail Bakhtin. He developed the concept of carnivalization, based on the outlook of the medieval carnival. The main task of carnivalization, the source of which the carnival worldview is, is the restoration of the original ambivalence of cultural meanings, the destruction of artificial monological barriers between closed systems of thinking and the types of worldviews that carnivalization contrasts with ambivalent, personalistic and systematic values. As Mikhail Bakhtin notes, the carnival beginning plays an important role in the cultural dynamics - contributes to the "renewal of culture, its peculiar respiration, its exit from the systems and regulations of the previous time" (Bakhtin, MM Aesthetics of verbal creativity, p. 40 , because it is related to the spread and development of new cultural meanings, the ironic rethinking of the past. Thus, "carnivalization" contributes to the formation of a new worldview, the transition to a qualitatively different cultural and philosophical level.

Modern researchers (K. Galton, M. Zagibalova, L. Langman, V. Nesterov, E. Nesterov, V. Samokhin, T. Fedyaev, O. Maltseva etc.) pay considerable attention to the concept of Mikhail Bakhtin and say that it is possible to use it for the study of contemporary culture. In particular, the terms "carnival", "carnival", "carnivalization" are used in the study of the phenomena of modern culture, because they to some extent reveal the meaning of these phenomena.

Particularly striking is the phenomenon of carnivalization of modern culture manifesting itself within the mass culture, which, according to Jean Baudrillard, has a special spontaneous form of humor - hyperconformism, and thus has a laughable beginning, indicating the signs of carnivalization. The focus on bright theatricality and bright entertainment is a characteristic feature of contemporary mass art.

One of the hallmarks of modern culture is the new type of communication that has emerged under the influence of globalization and computerization. The computer world offers man a variety of opportunities for information exchange and communication in the "space of freedom". The virtual reality of the "computer world" gives a person new opportunities to move beyond everyday life, everyday life, to symbolically transcend oneself, to go abroad, to go beyond their social status, age, gender, even humanity. A special type of reality is created, built on the principles of the game, the main manifestations of which coincide with the game aspect of the carnival. This gives grounds to claim that virtual reality creates a carnival space.

Mass culture often uses the carnival principle with its semantic "werewolves". The contemporary cultural space includes various cultural phenomena, the interaction of which creates the conditions for the functioning of the carnivalization phenomenon. In view of this, we can speak of a special "carnival" worldview inherent in the carnival as a form of festive culture, one of the peculiarities of which is the modeling of a particular concept of reality. The worldview of the carnival is revealed through a system of categories such as "carnival laughter", "carnival freedom", "carnival behavior", "ambivalence," reflecting the peculiarities of evaluating, comprehending, and experiencing the outside world by its participants (Troitska T., Troitska O., Popravko, 2018: 68).

Analyzing the category of "carnival laughter", let us first of all pay attention to the fact that laughter in general is fundamental, cross-cutting and multidimensional in human existence - it is an important means of establishing contact between people. In this sense, it can be considered not only as a factor in overcoming the spiritual distance between representatives of different (alien) cultures, but also cultures in general.

Carnival laughter has its own peculiarities. Exploring his nature, Mikhail Bakhtin identifies such characteristic features as nationality, universality, ambivalence: "Carnival laughter is, first of all, national (nationality is embedded in 
the very nature of the carnival); secondly, it is universal, ie aimed at everyone and everyone (including the participants of the carnival), the whole world seems funny, perceived and comprehended in its ridiculous aspect; thirdly, this laughter is ambivalent, it is cheerful, joyful and at the same time mocking, it denies and states, it hides and revives" (Bakhtin, 1965: 10-11).

Mikhail Bakhtin reveals the foundational foundations of a laugh culture, defining it as "a cultural and psychological phenomenon that expresses a person's ability to comically assess reality". Laughter, in his opinion, is a form of truth about the surrounding reality. This particular universal view of the world, which sees it differently, is no less important than seriousness, because, by rejecting the ridiculous aspect of any phenomenon, we lose ourselves the full knowledge of it.

The philosophical significance of carnival laughter is that it offers one's own vision of the world. And in this sense, the comic comes before us as a certain concept of reality. Sincere human laughter is something that can help a person find some meaning. However, laughter as a reaction to the understanding of the world arises only when a person begins to understand the world in a new way, when he overcomes the fear of his own, limited understanding of the world. Laughter opens the world to man in a new way, because it reveals contradictions that exist in reality. Therefore, it "contains a certain part of discontent, anger and pain" (Golozubov, 2009: 20).

The character of carnival laughter is conditioned by specific historical conditions, but this does not diminish its ideological significance within a certain socio-cultural context. On the contrary, such laughter overcomes the contradictions of a particular historical era. In the space of the carnival is formed a certain holistic space in which a special vision of the world is formed, based on fun, humor, self-irony. Participants of the holiday, being in it and feeling part of it, acquire the ability to easily relate to themselves and the world. The funny aspect of modern carnivals has its own specificity, since "in postmodernism there are practically no such emotional colors as fun or humor" (Bulavka, 2000: 127). Because, as we noted earlier, the culture of the postmodern destroys the principle of the "whole", which is "not afraid of self-criticism", "free from inferiority complex, as well as from other complexes", "extraverted in nature and living, opening up to the world" (Ibid). However, carnival laughter does not lose its overall socio-cultural significance. The essence of laughter lies in the formation of human spirituality, which indicates its connection with freedom. It saves the person from the hopelessness, elevates him over the situation. This feature of laughter is especially important in a crisis era.

The category "carnival freedom" reflects the ability to feel freedom emotionally. Because it is characterized by joy or novelty and associated with the release from the norms of everyday life and rules of normal behavior, the elimination of psychological complexes, overcoming the state of dissatisfaction, fear or alienation. This is not only freedom from something - work, daily life; however, it is freedom "for" the person himself - a positive confirmation of his creative abilities and improvisation.

In the context of cultural dialogue, carnival freedom is defined as the subject's ability to co-create through communication. It should be noted that in this case, creativity, we mean social, that is, "the joint co-creation of new social relations by free persons, actors in the Dialogue process; this co-creation is, of course, limited by objective laws, but not determined by alienation relations; moreover, it destroys the latter, releasing the person in his immediate social life, not outside him" (Bulavka, 2000: 123).
The analysis of various aspects of the manifestation of freedom in the carnival shows that its character and degree of realization are historically determined, that is, are directly dependent on the socio-political and cultural processes that take place in a particular society. The category of "carnival behavior" is characterized by a playful character, which follows from the definition of the carnival as "organized by certain rules of game action, devoid of direct practical expediency, which gives an individual the possibility of self-realization that goes beyond his actual social roles" (Gritsanov, Mozheyko, 2001: 292).

Specificity of realization of game behavior in the space of the carnival is determined by mass character and obligatory presence of comic elements, which gives it a special meaning and distinguishes it among other types of game: "In the carnival life plays itself, playing - without stage, without ramp, without actors, without the spectators, that is, without any artistic and theatrical specifics - another free form of its realization, its revival and updating on the best principles. This is the specific nature of the carnival, a special kind of its existence (Bakhtin, 1965: 10-11).

In the game space of the carnival is simulated a special reality that can coincide with the surrounding reality, complement it, or, on the contrary, to confront it. This is based on the human tendency to personify when life is "reproduced" as an aesthetic activity, an experience when all mental processes find their way out in reproducible situations. With this kind of rethinking, one tries to find the answers to important questions that are relevant to one's understanding of the world and an awareness of one's place in one. It should be noted that in this case an important role belongs to the symbolic and symbolic understanding of reality, which is actualized in the carnival. The manifestation of the symbolic perception and development of the world is the creation of "doubles" of man - masks, dolls, masquerade costumes, the sacred nature of which testifies to the person to overcome the border of time and space, real and hyperreal.

Thus, the play behavior in the space of the carnival is based on the emotional and rational aspects of the perception of reality. That is, on the one hand, it is caused by a special game atmosphere based on the emotional experiences of the players, and on the other - by strict adherence to certain rules, violation of which leads to leaving the game".

"Ambivalence" as a category of carnival implies an appeal to the principle of binary. In the postmodern culture, the idea of the complex nature of relationships between the extreme poles of binary oppositions is established, based on their interaction and interpenetration rather than on opposition. Relationships of this nature determine the ambivalent nature of the carnival. Michael Bakhtin said that in the formal contrast of meaning and tone, in the subjective game of opposites, there is an objective ambivalence of being, an objective coincidence of opposites, which, although not thought clearly, is to some extent felt by the participants of the carnival (Bakhtin, 1965: 7-16; 2027; 119-126; 165-167).

Thus, ambivalence as an attribute of a carnival lies in the parallel existence in its semantic space of different points of view on the same phenomenon or process, which complement each other, ensuring the integrity of the picture of the world that is formed within the given holiday. Moreover, the fact that neither of these judgments is given final preference increases the inexhaustibility of the hidden possibilities of the symbolic space of the carnival. The views of the world present in the carnival, depending on the cultural and historical context, occupy a dominant place, thus determining the nature of the holiday. Within 
the contemporary sociocultural situation, a "new type of mentality and semiotization of the space of life" is formed, when "no intellectual or moral system, no way of perceiving reality can be definitively legitimized, nothing can claim a definitive advantage" (Gritsenko, 1999: 208).

Therefore, the ambivalent nature of the carnival, on the one hand, causes a certain unpredictability and variability of development, and on the other" - allows to generate new meanings. It is the ambivalent nature of the carnival that makes it possible to attain universality of perception of the world and of man, which determines its relevance over a long period of history.

\section{Conclusions}

Analyzing contemporary philosophical and cultural concepts, the trends that indicate a transitional stage of cultural development have been identified. This is primarily manifested in the blurring of temporal and spatial boundaries of culture, interpenetration and even interchangeability of "alien" elements to each other. As a result, there is a tendency towards carnivalization, when any cultural space is granted carnival status. This situation necessitates an appeal to the concept of carnivalization, which will help to reveal the meaning of various manifestations of modern culture.

Investigating the peculiar dialogue of medieval and modern culture, the worldview of carnivalization was revealed as a phenomenon of the modern transitional stage of cultural development. It is determined that carnivalization is a special way of restoring the integrity of the worldview, since the laughter underlying it reveals the existing contradictions and thus brings it closer to the knowledge of truth. It is laughter that creates the space for dialogue between specific people and between cultures.

An analysis of such a dialogue of cultures makes it possible to identify the moments caused by the manifestation of the laugh-outbreak inherent in the carnival. Volodymyr Kormer writes: "Forgetting this ridiculous corrective, forgetting about it, we risk not understanding something in the things that are truly serious and important that are relevant to all of our current culture and its future" (Kormer, 1991: 185).

The carnivalization of contemporary culture fully reflects the essence of the contemporary crisis of culture. Any crisis is often seen as death, and indeed, a crisis stage in development is overcoming difficulties, the transition to a new state, and therefore the death of the old and the old. We hope that the crisis of modern culture will be successfully overcome and the modern society, "fed up" with the carnival festivity that has filled the everyday life, will move to a new stage of its development, will come to a new understanding of social, political, economic, every day and festive part of our life.

We hope that this will help to establish the ideas of Truth, Good and Beauty. It is precisely the praxeological dimension of the process of carnivalization, contemporary cultural practices and the lifeworld that should be the subject of prospective further research.

\section{REFERENCES}

Bakhtin, M. M. (1965). Tvorchestvo Fransua Rable i narodnaya kultura srednevekovya i Renessansa. Moscow: Khudozhestvennaya literatura, 541 p. (In Russian)

Bakhtin, M. M. (1979). Estetika slovesnogo tvorchestva. Moscow: Iskusstvo, 423 p. (In Russian)

Bandlamudi, L. (2015). Carnivalization of consciousness a Catalyst for Development. In: Difference, Dialogue, and Development: a Bakhtinian World. New York: Routledge, P. 63-86. DOI: https://doi.org/10.4324/9781315669335
Braun, J. (2012). Alienation and the Carnivalization of Society Preface. In: Alienation and the carnivalization of society. Routledge Studies in Social and Political Thought.

Bulavka, L. A. (2000). Bakhtin: dialektika dialoga versus metafizika postmoderna. Voprosy filosofii, 1: 119-131 (In Russian)

Eko, U. (2007). Polnyy nazad! "Goryachie voyny" i populizm v SMI [translate by Ye. Kostyukovich]. Moscow: Eksmo, 592 p. (In Russian)

Golozubov, A. V. (2009). Teologiya smekha kak fenomen zapadnoy kulturi. Kharkov: Eksklyuziv Publishing, 468 p. (In Russian)

Gritsanov, M. A. (ed.) and Mozheyko, A. A. (2001). Postmodernizm. In: Entsiklopediya. Retrieved from http://www.gumer.info/ bogoslov_Buks/Philos/PostModern/59.php (In Russian)

Gritsenko, V. P. (1999). Kultursemiotika: Opyt sistematicheskogo izlozheniya. Krasnodar: KGUKI, 372 p. (In Russian)

Khrenov, N. (2002). Kultura $v$ epokhu sotsialnogo khaosa. Moscow: Editorial URSS, 448 p. (In Russian)

Kormer, V. F. (1991). O karnavalizatsii kak genezise "dvoynogo soznaniya". Voprosy filosofii, 1: 166-185 (In Russian)

Lotman, Y. M. (1992). Kultura i vzryv. Moscow: Gnozis, 272 p. (In Russian)

Maltseva, O. (2018). The phenomenon of the carnivalization of sport in postmodern society. Skhid, 1(153), 108-120. DOI: https:/ /doi.org/10.21847/1728-9343.2018.1(153).127538

Mironov, V. V. (1996). Nauka i "krizis kultury" (ili zatyanuvshiysya karnaval?). Vestnik Moskovskogo universiteta. Seria Filosofiya. 4: 3-13. (In Russian)

Nazintsev, V. V. (1997). Smekhovaya sinergetika mira. Dialog. Karnaval. Khronotop. 1: 34-60 (In Russian)

Semenova, Y. A. (2013). Aktualizatsiya karnavalnykh protsessov $v$ period krizisa kultury (na primere subkultury studenchestva). Problemy sovremennogo obrazovaniya. 5: 150-159 (In Russian).

Sharnina, M. (2016). The dialectic of neo-mythological patterns of the development of "carnival ritual" person in the works by Yuriy Andrukhovych. Skhid, 6 (146). DOI: https://doi.org/10.21847/ 1728-9343.2016.6(146).78856 (In Ukrainian)

Shcherbakova, N. V. (2015). Ideological support of transformations for youth value instructions as a determinant of their moral development optimization: philosophical aspect. VERSUS. 1(5): 89-94. Retrieved from http://magazine.mdpu.org.ua/index.php/versus/article/view/1253 (In Ukrainian)

Troitska, O. M. (2016). Dialog i dialogichnist v kulturno-osvitnomu prostori: filosofski zasadi. Humanitarian Bulletin of Zaporozhye State Engineering Academy. 65: 50-57. DOI: https://doi.org/ 10.30839/2072-7941.2016.71166 (In Ukrainian)

Troitska, T., Troitska O., Popravko O. (2018). The value-semantic essence of the holiday and its role in the harmonization of the cultural being of the modern man. VERSUS. 1-2 (11-12): 67-72. DOI: https://doi.org/10.33842/2313-4562/2018/11/16/72 (In Ukrainian)

Zagibalova, M. A. (2011). Osobennosti kulturnogo razvitiya sovremennosti: fenomen karnavalizatsii. Izvestiya Tulskogo gosudarstvennogo universiteta. Gumanitarnye nauki. 2: 32-39. (In Russian)

Zagibalova, M. A. (2013). Karnaval i karnavalizatsiya kak pogranichnye fenomeny kultury. Izvestiya Volgogradskogo gosudarstvennogo tekhnicheskogo universiteta. Seriya: problemy sotsialno-gumanitarnogo znaniya. 13(9): 96-98. (In Russian)

\section{LIST OF REFERENCE LINKS}

Бахтин М. М. Творчество Франсуа Рабле и народная культура средневековья и Ренессанса. Москва: Худож. лит., 1965. $541 \mathrm{c}$.

Бахтин М. М. Эстетика словесного творчества. Москва: Искусство, 1979. 423 с.

Булавка Л. А. Бахтин: диалектика диалога versus метафизика постмодерна. Вопросы философиии. 2000. № 1. С. 119-131.

Голозубов А. В. Теология смеха как феномен западной культуры. Харьков: ТО "Эксклюзив", 2009. 468 с.

Гриценко В. П. Культурсемиотика: Опыт систематического изложения. Краснодар: КГУКИ, 1999. 372 с.

Загибалова М. А. Карнавал и карнавализация как по- 
граничные феномены культуры. Известия Волгоградского государственного технического университет. Серия: проблемы социально-гуманитарного знания. 2013. 13(9). С. 96-98.

Загибалова М. А. Особенности культурного развития современности: феномен карнавализации. Известия Тульского государственного университета. Гуманитарные науки. 2011. 2. C. 32-39.

Кормер В. Ф. О карнавализации как генезисе "двойного сознания". Вопросы фрилософрии. 199. № 1. С. 166-185.

Лотман Ю. М. Культура и взрыв. Москва: Гнозис, 1992. 272 c

Мальцева О. Феномен карнавалізації спорту в постмодерному суспільстві. Cхід. 2018. № 1(153). C. 108-120. DOI: https://doi.org/10.21847/1728-9343.2018.1(153).127538

Миронов В. В. Наука и "кризис культуры" (или затянувшийся карнавал?). Вестник Московского университета. Сeрия Философия. 1996. № 4. С. 3-13.

Назинцев В. В. Смехова синергетика мира. Диалог. Карнавал. Хронотоп. 1997. № 1. С. 34-60.

Постмодернизм: Энциклопедия / сост. и науч. ред. А. А. Грицанов, М. А. Можейко. Минск: Интерпрессервис, 2001. URL: http://www.gumer.info/bogoslov_Buks/Philos/PostModern/ _59.php

Семенова Я. А. Актуализация карнавальных процессов в период кризиса культуры (на примере субкультуры студенчества). Проблемы современного образования. 2013. 5. C. 150-159.
Троїцька О. М. Діалог і діалогічність в культурно-освітньому просторі: філософські засади. Гуманітарний вісник Запорізької державної інженерної академії. 2016. № 65. С. 50-57.

Троїцька Т. С., Троїцька О. М., Поправко О. В. Ціннісносмислова основа свята і його роль у гармонізації культурного буття сучасної людини. VERSUS. Науково-теоретичний часопис. 2018. № 1-2 (11-12). С. 67-72.

Хренов Н. Культура в эпоху социального хаоса. Москва: Едиториал URSS, 2002. 448 с.

Шарніна М. Діалектика неоміфологічних закономірностей розвитку "карнавально-ритуальної" людини Ю. Андруховича. Cxid. 2016. 6 (146). DOI: https://doi.org/10.21847/17289343.2016.6(146).78856

Щербакова Н. В. Ідеологічний супровід трансформацій ціннісних настанов молоді як детермінанта оптимізації розвитку її моралі: фрілософський аспект. VERSUS. Науково-теоретичний часопис. 2015. № 1(5) С. 89-94.

Эко У. Полный назад! "Горячие войны" и популизм в СМИ; [пер. Е. Костюкович]. Москва: Эксмо, 2007. 592 с.

Bandlamudi L. Carnivalization of consciousness a Catalyst for Development. In: Difference, Dialogue, and Development: a Bakhtinian World. New York: Routledge, 2015. P. 63-86. DOI: https://doi.org/10.4324/9781315669335

Braun J. Alienation and the Carnivalization of Society Preface. In: Alienation and the carnivalization of society. Routledge Studies in Social and Political Thought, 2012.

Олена Тройцька,

Мелітопольський державний педагогічний університет ім. Б. Хмельницького (м. Мелітополь, Украӥна) e-mail: troizka2015@ukr.net,ORCID0000-0003-4330-084X

Ольга Поправко,

Мелітопольський держсавний педагогічний університет ім. Б. Хмельницького (м. Мелітополь, Украӥна) e-mail: popravko_olga@ukr.net, ORCID0000-0002-4765-2300

Ніна Щербакова,

Мелітопольське відділення Таврійського держсавного агротехнологічного університету

імені Дмитра Моторного (м. Мелітополь, Украӥна)

e-mail: rnk-07@ukr.net,ORCID 0000-0003-2632-2641

\section{АСПЕКТИ "КАРНАВАЛІЗАЦІЇ" СУЧАСНИХ КУЛЬТУРНИХПРАКТИК}

Актуальність статті обумовлена необхідністю осмислення нового культурного феномена, який презентує культурні практики сучасного хронотопу. Проаналізовано філософсьько-культурологічні концепції стану культури та виявлено тенденції, які відображають нестійкість (перехідність), невизначеність, амбівалентність культурних практик і карнавалізацію усіх сфер буття. Філософська рефлексія сутності, характеру, ознак карнавалізації уможливила експлікацію феномена "карнавал" через його світоглядний і поведінковий компоненти. У контексті діалогу середньовічної та сучасної культури розкрито сутність карнавалізації як феномена культури та як особливого способу відновлення цілісності світосприйняття, світорозуміння, світовідношення і актуалізовано проблему орієнтації і спрямування культурних практик на їх ціннісно-смислове (аксіологічне) піднесення. Досліджено природу й сутність таких категорій, як "карнавальний сміх", "карнавальна свобода", "карнавальна поведінка", "амбівалентність", виявлено характерні ознаки карнавалізації та доведено, що її можна розглядати як спосіб моделювання і конструювання сучасної культурної дійсності. Обгрунтовано положення про те, що сучасний культурний простір створює умови не тільки для функціонування карнавалізації у межах першочергової функції - оновлення, становлення нового життєвого світу, але й нового світорозуміння та смислотворення. Визначено конструктивну роль діалогу культур у процесі праксеологічного зростання суб'єктів карнавалізації і показано, що концепція карнавалізації Михайла Бахтіна залишається актуальною на сучасному етапі розвитку культури. Розкриття карнавалізації як певного сигналу кризи культури і способу виходу 3 неї дає підстави розглядати карнавалізацію як чинник самоорганізації культури, як складноорганізованої системи.

Ключові слова: аксіологія; діалог культур; карнавалізація; карнавальна поведінка; карнавальний світогляд; криза культури; культурні практики; культурні смисли.

() Olena Troitska, Olga Popravko, Nina Shcherbakova

Надійшла до редакції: 15.01.2020

Прийнята до друку: 31.01.2020

ISSN 1728-9343 (Print)

ISSN 2411-3093 (Online)

SKHID No. 1 (165) January-February 2020 